\title{
A novel method of neural differentiation of PC12 cells by using Opti-MEM as a basic induction medium
}

\author{
RENDONG HU $^{1 *}$, QIAOYU CAO ${ }^{2 *}$, ZHONGQING SUN ${ }^{3}$, JINYING CHEN $^{4}$, QING ZHENG $^{2}$ and FEI XIAO ${ }^{1}$ \\ ${ }^{1}$ Department of Pharmacology, School of Medicine, Jinan University; ${ }^{2}$ College of Pharmacy, Jinan University, \\ Guangzhou, Guangdong 510632; ${ }^{3}$ Department of Anesthesia and Intensive Care, Faculty of Medicine, \\ The Chinese University of Hong Kong, Hong Kong 999077, SAR; ${ }^{4}$ Department of Ophthalmology, \\ The First Clinical Medical College of Jinan University, Guangzhou, Guangdong 510632, P.R. China
}

Received April 5, 2017; Accepted October 11, 2017

DOI: 10.3892/ijmm.2017.3195

\begin{abstract}
The PC12 cell line is a classical neuronal cell model due to its ability to acquire the sympathetic neurons features when deal with nerve growth factor (NGF). In the present study, the authors used a variety of different methods to induce PC12 cells, such as Opti-MEM medium containing different concentrations of fetal bovine serum (FBS) and horse serum compared with RPMI-1640 medium, and then observed the neurite length, differentiation, adhesion, cell proliferation and action potential, as well as the protein levels of axonal growth-associated protein 43 (GAP-43) and synaptic protein synapsin-1, among other differences. Compared with the conventional RPMI-1640 medium induction method, the new approach significantly improved the neurite length of induced cells (2.7 times longer), differentiation rate (30\% increase), adhesion rate (21\% increase) and expression of GAP-43 and synapsin-1 (three times), as well as reduced cell proliferation. The morphology of induced cells in Opti-MEM medium containing $0.5 \%$ FBS was more like that of neurons. Additionally, induced cells were also able to motivate the action potential after treatment for 6 days. Therefore, the research provided a novel, improved induction method of neural differentiation of PC12 cells using Opti-MEM medium containing $0.5 \% \mathrm{FBS}$, resulting in a better neuronal model cell line that can be widely used in neurobiology and neuropharmacology research.
\end{abstract}

Correspondence to: Dr Fei Xiao, Department of Pharmacology, School of Medicine, Jinan University, 601 West Huangpu Avenue, Guangzhou, Guangdong 510632, P.R. China

E-mail: xiaofei@jnu.edu.cn

Professor Qing Zheng, College of Pharmacy, Jinan University, 601 West Huangpu Avenue, Guangzhou, Guangdong 510632, P.R. China

E-mail: tzhengq@jnu.edu.cn

*Contributed equally

Key words: PC12 cells, neural differentiation, Opti-MEM, induced method

\section{Introduction}

The PC12 cell line is traceable to a pheochromocytoma from the rat adrenal medulla (1-4). When exposed to nerve growth factor (NGF), PC12 cells present an observable change in sympathetic neuron phenotype and properties. Neural differentiation of PC12 has been widely used as a neuron cell model in neuroscience, such as in the nerve injury-induced neuropathic pain model (5) and nitric oxide-induced neurotoxicity model (6). NGF induces differentiation of PC12 cells by acting through the TrkA receptor (7).

Differentiation of PC12 cells is assessed by semi-quantitative or quantitative morphological methods. These methods can include the measurement of the cell size, neurite number and neurite length. Additionally, neurotypic and gliotypic proteins have been used as biochemical markers of neurotoxicity (8). In general, differentiated PC12 cells have been widely used in both neurobiological and neurotoxicological studies as a model of neuronal differentiation.

At present, there are many different differentiation methods. Greene and Tischler (9) first demonstrated that PC12 cells generated in RPMI-1640 medium retained their tumorigenic properties and were sensitive to nerve growth factor protein, but the PC12 neuronal processes only reached 500-1,000 $\mu \mathrm{m}$ in length.Cell differentiation was increasing following replacing the Dulbecco's modified Eagle's medium (DMEM) containing 10\% FBS and $10 \%$ horse serum (HS) with fresh medium containing $50 \mathrm{ng} / \mathrm{ml}$ NGF. The results reported that PC12 cells did not proliferate and started to differentiate into neuron-like cells, but the increase in cell number reached $51.09 \pm 9.3 \times 10^{4}$ cells $/ \mathrm{ml}(10)$. PC12 cells grown in DMEM medium containing 1\% HS and $0.5 \% \mathrm{FBS}$ then were treated with $100 \mathrm{ng} / \mathrm{ml} \mathrm{NGF,} 100 \mathrm{ng} / \mathrm{ml}$ basic fibroblast growth factor (bFGF) and $1 \mathrm{mM}$ cAMP in serum-starved media containing antibiotics and $2 \mathrm{mg} / \mathrm{ml} \mathrm{BSA}$ for 2 days. The results indicated that Tau-1 and synaptotagmin were localized at the neurite tips (11).

The problems with the traditional methods are the limited neurite outgrowth, high proliferation rate, low differentiation rate and lack of synapse-like structures. Methods with which to improve the morphological differentiation and physiological function of PC12 cells in order to make them more similar to neurons are urgently required. In the present study, by 
comparing traditional induction method and observed the neurite length, differentiation, adhesion, cell proliferation and action potential of the induced PC12 cells in addition to the protein levels of axonal GAP-43 and synaptic protein synapsin-1. The research introduces a novel, improved induction method involving the use of Opti-MEM medium containing $0.5 \%$ FBS to induce PC12 cells, resulting in a better neuron cell model than the traditional method of induction.

\section{Materials and methods}

Reagents. The following materials were used in this study, Cy3-conjugated Goat Anti-Rabbit secondary antibody (Abcam, Cambridge, UK). MTT (Sigma-Aldrich; Merck KGaA, Darmstadt, Germany), Matrigel (BD Biosciences, Franklin Lakes, NJ, USA), poly-L-lysine (PLL; Sigma-Aldrich; Merck KGaA), fetal bovine serum (FBS) and HS (both from Gibco; Thermo Fisher Scientific, Inc., Waltham, MA, USA), GAP-43 antibody (ab75810; Abcam), synapsin-1 antibody (SAB1412529; Sigma-Aldrich; Merck KGaA), PBS tablet (BD Biosciences), NGF (Hiteck Biological Pharma Co., Ltd., Wuhan, China), Protease Inhibitor Cocktail Set I (539131; Millipore, Billerica, MA, USA), and anti-tubulin- $\beta$ III antibody (Sigma-Aldrich; Merck KGaA).

Cell culture. PC12 cells were preserved in our laboratory (Institute of Brain Sciences, Jinan University). PC12 cells were cultured in RPMI-1640 medium supplemented with $10 \%$ HS, 5\% FBS, $100 \mathrm{U} / \mathrm{ml}$ penicillin and $100 \mathrm{mg} / \mathrm{l}$ streptomycin. PC12 cells were all maintained at $37^{\circ} \mathrm{C}$ in a $95 \%$ humidified incubator with $5 \% \mathrm{CO}_{2}$ before the experiments.

Differentiation. PC12 cells were plated at low density $\left(2 \times 10^{3}\right.$ cells $\left./ \mathrm{cm}^{2}\right)$ in RPMI-1640 medium supplemented with $10 \%$ normal HS, 5\% FBS and penicillin-streptomycin. At $2 \mathrm{~h}$ after plating, the medium was replaced with serum-free 1640/Opti-MEM medium containing $50 \mathrm{ng} / \mathrm{ml}$ NGF. Cells treated with culture medium alone were used as the control. Cells were fed 1640/Opti-MEM medium on days $0,2,4$ and 6 containing $50 \mathrm{ng} / \mathrm{ml} \mathrm{NGF}$ and $0.5 \% \mathrm{FBS}$ or $1 \% \mathrm{HS}$ and $0.5 \%$ FBS.

Neurite outgrowth assay. Chamber slides were coated with $0.01 \%$ PLL at room temperature overnight. PC12 cells were plated at a density of $1 \times 10^{4}$ cells/well in a volume of $100 \mu 1$. After $24 \mathrm{~h}$, fresh media with NGF $(25,50$ and $100 \mathrm{ng} / \mathrm{ml})$ was added and incubated for $24 \mathrm{~h}$. Cells were fixed with $4 \%$ paraformaldehyde and incubated with a mouse anti-tubulin- $\beta$ III antibody (1:800). Each group was evaluated in duplicate, and the experiments were repeated four times. The percentage of neurite outgrowth was quantified, and neurons with neurites longer than the diameter of the cell body were considered to be 'neurite-bearing'. The average neurite length of each neuron was measured with Image-Pro Plus software (Media Cybernetics, Inc., Rockville, MD, USA). A total of 100 neurons were measured from each group. Morphometric analysis was performed on digitized images. Images were taken with an average of 10 cells/field. The number of differentiated cells was expressed as a percentage of the total cells in the field and counting cells that had at least one neurite with a length equal to the cell body diameter. Experiments were repeated at least three times using cultures prepared on separate days.

Cell adhesion. A total of 96 wells were treated with $50 \mu \mathrm{l}$ of Matrigel at $37^{\circ} \mathrm{C}$ and $5 \% \mathrm{CO}_{2}$ for $1 \mathrm{~h}$, and incubated in $1 \% \mathrm{BSA}$ for $1 \mathrm{~h}$ after washing twice with PBS. The 96 wells were washed two more times with PBS before plating with $1.0 \times 10^{5} / \mathrm{ml}$ cell suspension density in a volume of $100 \mu \mathrm{l}$ at $37^{\circ} \mathrm{C}$ and $5 \% \mathrm{CO}_{2}$ for different times $(0.5,1,2,3,4,5$ and $6 \mathrm{~h})$. In each group, half of the wells without PBS washing and the other half of the wells that were treated with warm PBS wash demonstrated cell adhesion disruption. Cell viability was evaluated with the MTT experiment after measuring the well absorbance value $(\mathrm{A}$ value $)$. The ratio $=(\mathrm{A}$ value/total adhesion cells A value) $x 100 \%$. Following $2 \mathrm{~h}$ of incubation, the medium was replaced with Opti-MEM/1640.

Cell counts. PC12 cells $\left(7 \times 10^{4}\right.$ cells $\left./ \mathrm{ml}\right)$ were plated on a $35 \mathrm{~mm}^{2}$ plastic dish and counted daily. Cells were incubated under the conditions described above for various time of durations, and the medium was replaced every 2 days. Cells was centrifuged and harvested after trypsinization (0.025\% trypsin-EDTA). The collected cells were transferred to a new tube, the suspension was mixed uniformity, and an aliquot of predetermined volume was placed to quantify the number of cells.

Western blot analysis. The expression levels of GAP-43 and synapsin-1 were quantified with western blot analysis. Cells $\left(1.3 \times 10^{4}\right.$ cells $\left./ \mathrm{cm}^{2}\right)$ were plated on 12 -well plates. The cells were collected by centrifugation at $1,000 \mathrm{x}$ g for $5 \mathrm{~min}$ at $4^{\circ} \mathrm{C}$. The supernatant was discarded, and cell pellets were sonicated for $15 \mathrm{sec}$ in ice-cold lysate buffer ( $20 \mathrm{mM}$ Tris, $\mathrm{pH} 7.5 ; 150 \mathrm{mM}$ $\mathrm{NaCl}, 1 \mathrm{mM}$ EDTA, $10 \%$ glycerol, $1 \%$ Triton X-100, 1 mM NaF, $1 \mathrm{mM} \mathrm{Na} \mathrm{VO}_{4}$ and 1:200 dilution of Protease Inhibitor Cocktail Set I). The cell lysate was centrifuged at $10,000 \mathrm{x}$ g for $10 \mathrm{~min}$ at $4^{\circ} \mathrm{C}$, and the supernatant was saved for analyses. Total protein was determined by bicinchoninic acid (BCA Protein Assay kit; Thermo Fisher Scientific, Inc.) method. For western blot analysis, the supernatant was added to an equal volume of loading buffer and heated to $95^{\circ} \mathrm{C}$ for $8 \mathrm{~min}$. Equal amounts of proteins $(0.125-2 \mathrm{mg} / \mathrm{ml})$ were separated by $12 \%$ SDS-PAGE and were transferred onto nitrocellulose membranes. The membranes were incubated with a monoclonal mouse GAP-43 antibody $(1: 1,000)$ or a polyclonal rabbit synapsin-1 antibody $(1: 1,000)$ overnight at $4^{\circ} \mathrm{C}$. Immunoreactivity was detected using a secondary antibody (1:5,000, ARG65351; Arigobio, Hsinchu, Taiwan) room temperature for $1 \mathrm{~h}$. Images were collected, and the band density was analyzed using a Fluor-S MultiImager and Quantity One software (Bio-Rad Laboratories, Inc., Hercules, CA, USA). Experiments were repeated four times on separate days.

Electrophysiology. Cells grown on coverslips with a recording chamber. Action potentials were recorded with a current-clamp whole-cell configuration. Patch micropipettes with resistance values of 8-10 M $\Omega$ were pulled with an electrode puller (P-97; Sutter Instrument Co., Novato, CA, USA). Pipettes were filled with solution containing $140 \mathrm{mM} \mathrm{KCl}$, $5 \mathrm{mM} \mathrm{NaCl}, 1 \mathrm{mM} \mathrm{CaCl}{ }_{2}, 10 \mathrm{mM}$ HEPES, $5 \mathrm{mM}$ EGTA and $2 \mathrm{mM}$ Na-ATP, and the $\mathrm{pH}$ was adjusted to 7.3. The standard external solution was composed of (in $\mathrm{mM}$ ) $140 \mathrm{NaCl}$, 


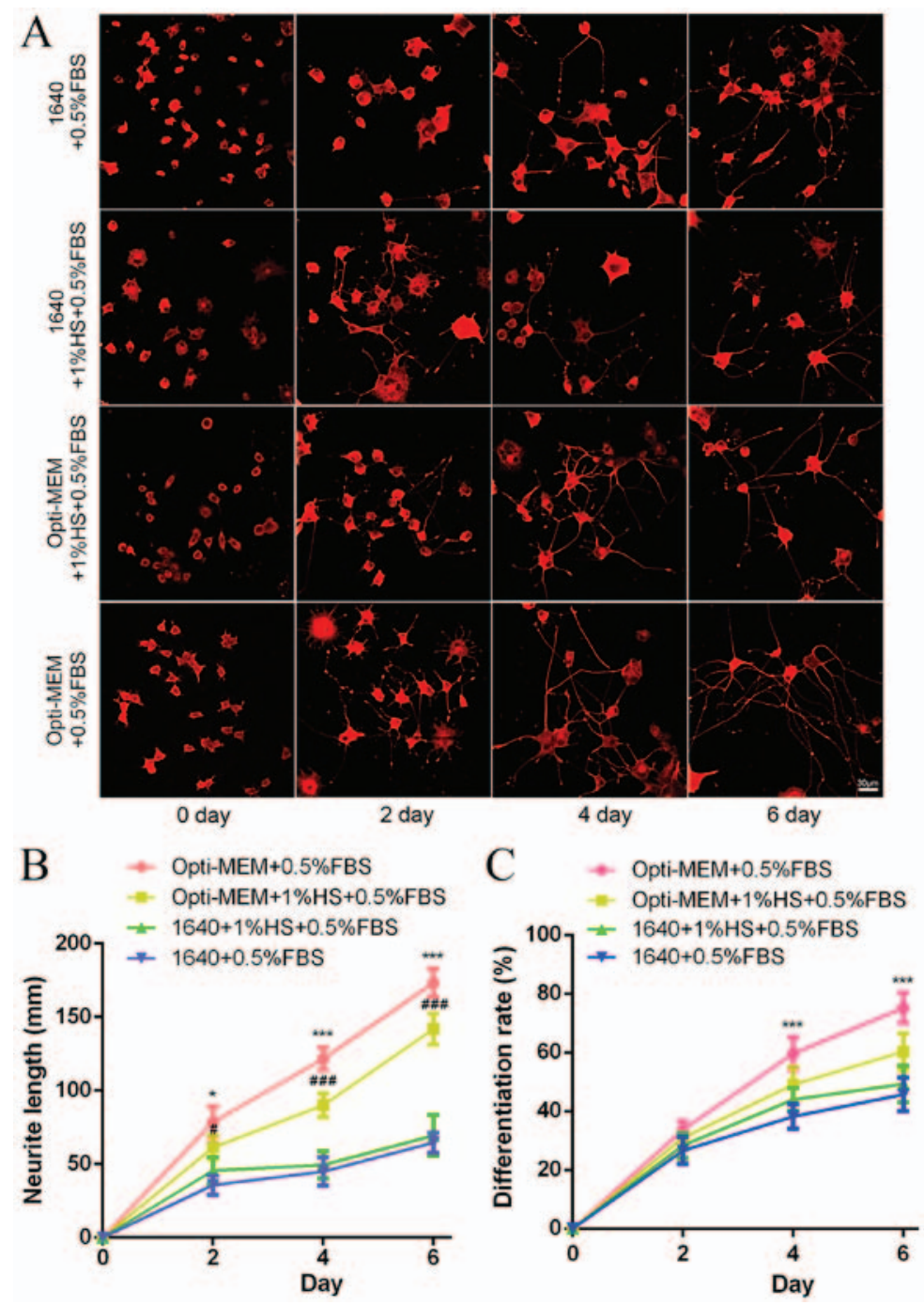

Figure 1. NGF-induced PC12 cells under different culture conditions. (A) NGF-induced differentiation of PC12 cells based on morphology (magnification, $\mathrm{x} 400$ ). (B) Effect of $50 \mathrm{ng} / \mathrm{ml} \mathrm{NGF}$ treatment on neurite growth. (C) Effect of differentiation treated with $50 \mathrm{ng} / \mathrm{ml}$ NGF. Data are presented as mean \pm standard error of the mean $(\mathrm{n}=10) .{ }^{*} \mathrm{P}<0.05,{ }^{* * * *} \mathrm{P}<0.001$ vs. $1640+0.5 \%$ FBS group; ${ }^{*} \mathrm{P}<0.05,{ }^{\# \# \#} \mathrm{P}<0.001$ vs. $1640+1 \%$ HS+0.5\% FBS group. NGF, nerve growth factor; FBS, fetal bovine serum.

$5 \mathrm{KCl}, 2.5 \mathrm{CaCl}_{2}, 1 \mathrm{MgCl}_{2}, 10$ glucose and $10 \mathrm{HEPES}$, and the $\mathrm{pH}$ was adjusted to 7.3 . Cells were perfused at $22-24^{\circ} \mathrm{C}$, and whole-cell currents were recorded using an EPC-10 patch clamp amplifier (HEKA Elektronik Dr. Schulze GmbH, Lambrecht, Germany). The membrane currents were low-pass filtered at $2.9 \mathrm{kHz}$ and sampled at $50 \mathrm{kHz}$, and the current injections ranged from -50 to $+90 \mathrm{pA}$ within $10 \mathrm{pA}$ steps. Data were collected with PatchMaster acquisition software (HEKA Elektronik Dr. Schulze GmbH); then, traces of the action potentials were displayed by Igor software (version 6.3; WaveMetrics, Lake Oswego, OR, USA).

Statistical analysis. All data are expressed as the mean \pm standard error of the mean. Analyses were performed using SPSS statistical software (version 16.0; SPSS, Inc., Chicago, IL, USA). Comparisons between groups were analyzed by one-way analysis of variance. The statistical significance was determined by Student's t-test for two groups. Multiple comparison between the groups was performed using SNK method. $\mathrm{P}<0.05$ was considered to indicate a statistically significant difference.

\section{Results}

The neurite length and differentiation rate of PC12 cells in different $N G F$-induced differentiation culture conditions. The effects of NGF $(50 \mathrm{ng} / \mathrm{ml})$ culture of PC12 cells is shown in Fig. 1.PC12 cells were fed $50 \mathrm{ng} / \mathrm{ml}$ NGF under different culture conditions on 0, 2, 4 and 6 days. NGF-induced differentiation of PC12 cells based on morphology are presented in Fig. 1A. For all culture conditions, the neurite length and cell differentiation were time-dependently increased (Fig. 1B and C). Compared with RPMI-1640 groups, the Opti-MEM medium group for 6 days resulted in an increased neurite length, and Opti-MEM medium containing $0.5 \%$ FBS was the best culture condition (Fig. 1B). The number of differentiated cells in Opti-MEM groups were higher than that in RPMI-1640, and the maximal extent of differentiated cells appeared in Opti-MEM medium containing 0.5\% FBS (Fig. 1C).

Neurite length of induced PC12 cells with different concentrations of NGF using Opti-MEM for different days. The two different conditions used induction in Opti-MEM medium 
A
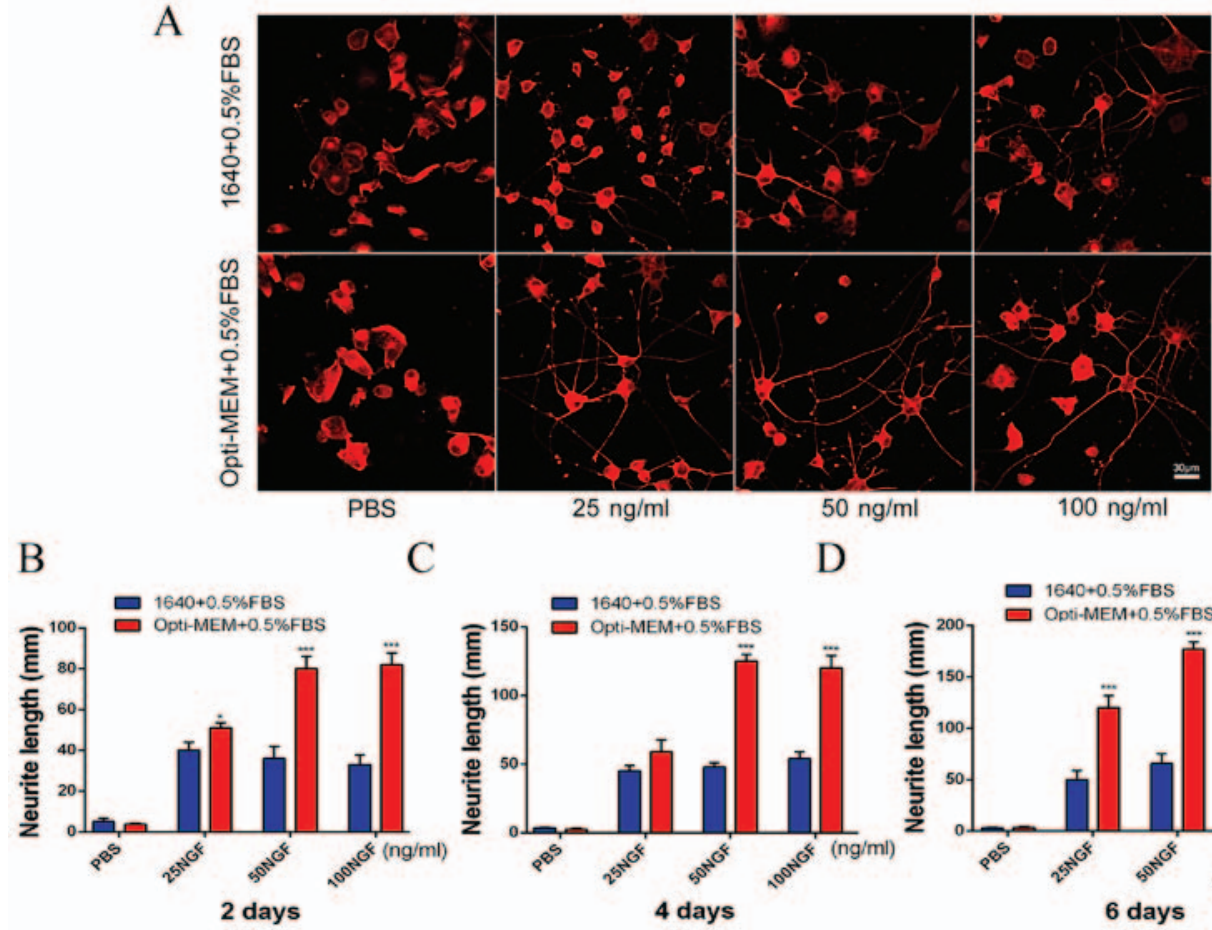

$\mathrm{C}$

$\mathrm{D}$
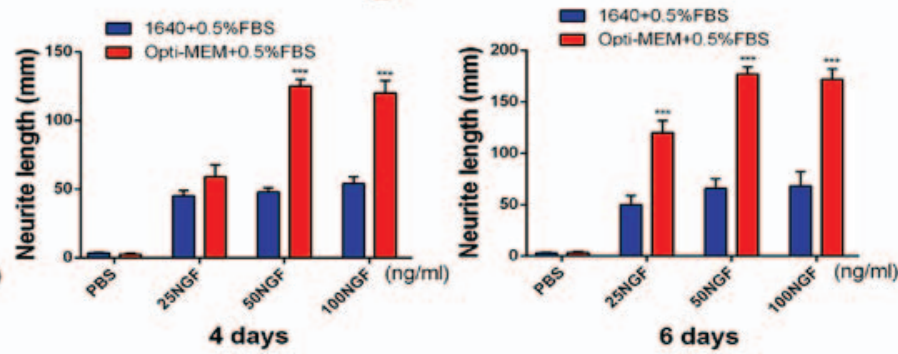

Figure 2. Neurite length of PC12 cells induced with different concentrations of NGF. (A) The effects of 0, 25,50 and $100 \mathrm{ng} / \mathrm{ml}$ NGF on the PC12 cell morphology was observed in the two groups on day 6 (magnification, x400). (B) Comparison of the neurite length of PC12 cells between the two groups on day 2. (C) Different neurite lengths of PC12 cells between the two groups on day 4. (D) Neurite length comparison of PC12 cells in the two groups on day 6. Data are presented as mean \pm standard error of the mean $(\mathrm{n}=10) .{ }^{*} \mathrm{P}<0.05$ and ${ }^{* * * *} \mathrm{P}<0.001$ vs. the $1640+0.5 \%$ FBS group. NGF, nerve growth factor; FBS, fetal bovine serum.

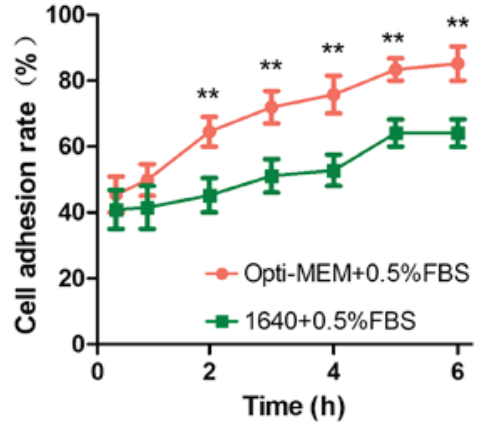

Figure 3. Comparison of the cell adhesion rate of PC12 cells between the Opti-MEM and 1640 groups. Data are presented as mean \pm standard error of the mean $(n=6) .{ }^{* *} \mathrm{P}<0.01$ vs. the $1640+0.5 \%$ FBS group.

containing $0.5 \%$ FBS or RPMI-1640 medium supplemented with $0.5 \%$ FBS. The effects of NGF at different concentrations and different time-points are presented in Fig. 2. The effects of $0,25,50$ and $100 \mathrm{ng} / \mathrm{ml} \mathrm{NGF}$ on the PC12 cell morphology was observed in the two groups on day 6 (Fig. 2A). Exposure of $\mathrm{PC} 12$ cells to different concentrations of NGF on day 2 resulted in concentration-dependent increases in the neurite length in Opti-MEM group, which was significant at $25 \mathrm{ng} / \mathrm{ml}$. However, the 1640 group results were the opposite (Fig. 2B). Exposure of PC12 cells to different concentrations of NGF on day 4 caused concentration-dependent increases in the neurite length. There was a significant increase in the neurite length in the Opti-MEM group with $50 \mathrm{ng} / \mathrm{ml} \mathrm{NGF} \mathrm{(Fig.} \mathrm{2C).} \mathrm{With} \mathrm{the} \mathrm{same} \mathrm{culture} \mathrm{and}$ induction conditions for PC12 as indicated in Fig. 2B and C, the authors found that the experimental group exposure to $50 \mathrm{ng} / \mathrm{ml}$ NGF on day 6 resulted in the greatest neurite length (Fig. 2D).

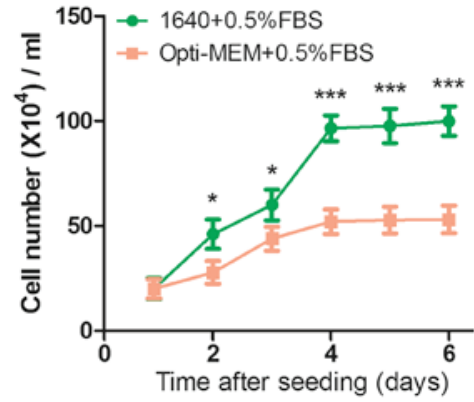

Figure 4. Comparison of PC12 cell proliferation between the Opti-MEM and 1640 groups. Data are presented as mean \pm standard error of the mean $(n=4)$ for 36 samples (two trials with 18 samples each). ${ }^{*} \mathrm{P}<0.05,{ }^{* * * *} \mathrm{P}<0.001$ vs. the $1640+0.5 \%$ FBS group.

Comparison of the cell adhesion rate of induced PC12 cells in the Opti-MEM and 1640 groups. PC12 cells were treated with $50 \mathrm{ng} / \mathrm{ml} \mathrm{NGF}$ at different time-points $(0.5,1,2,3,4,5$ and $6 \mathrm{~h})$ resulted in a time-dependent increase in the cell adhesion rate over the next $6 \mathrm{~h}$. It can be seen that Opti-MEM group compared with RPMI-1640 group resulted in a more obvious cell adhesion rate (Fig. 3).

Assessment of PC12 cell proliferation in the Opti-MEM and 1640 groups. Cells were cultured in the presence of serum and $50 \mathrm{ng} / \mathrm{ml} \mathrm{NGF}$, which enabled continuous proliferative activity. Cell growth rates were estimated and counting cell numbers every other day for 6 days. The authors found that the cell proliferation rate on RPMI-1640 group was higher than the Opti-MEM group during the experiment (Fig. 4). On day 2 , there were significantly more cells in the 1640 groups 

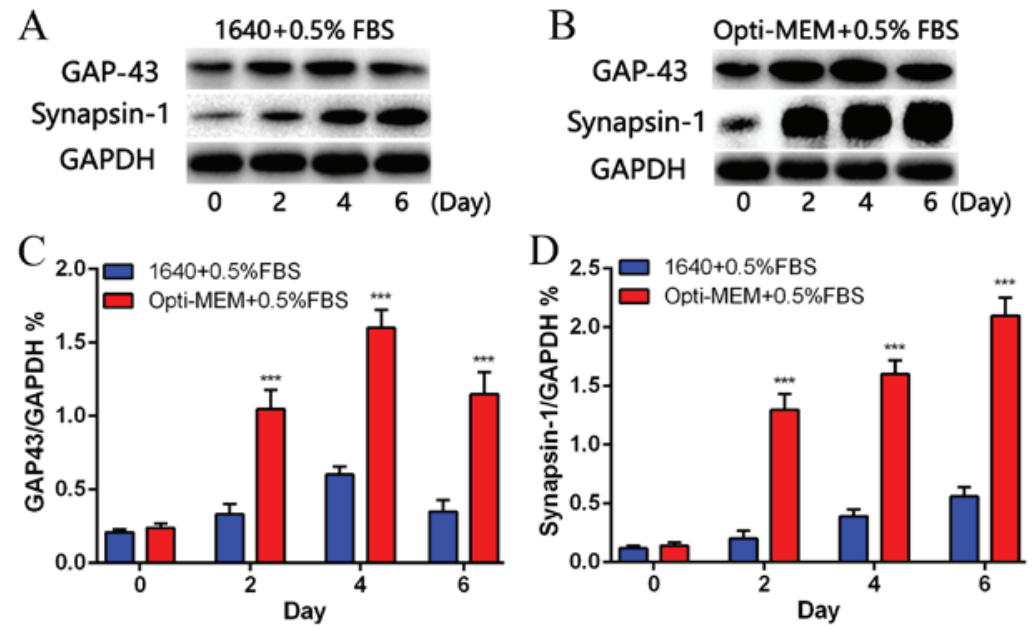

Figure 5. Protein expression was increased during NGF-induced differentiation of PC12 cells. (A) The synapsin-1 and GAP-43 levels in the $1640+0.5 \%$ FBS group. (B) The synapsin-1 and GAP-43 protein levels in the Opti-MEM+0.5\% FBS group. (C and D) Quantification of the GAP-43 and synapsin-1 protein levels in the two groups on days 2, 4 and 6. Data are presented as mean \pm standard error of the mean $(n=4) .{ }^{* * *} \mathrm{P}<0.001$ vs. the $1640+0.5 \%$ FBS group.

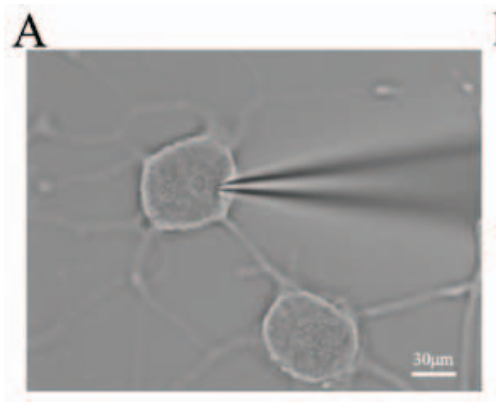

B

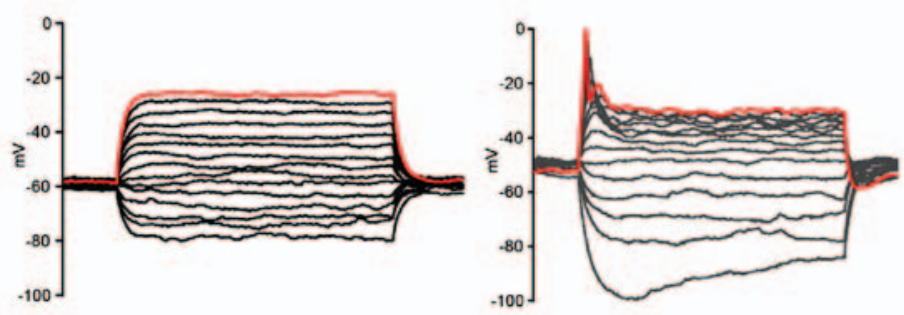

Figure 6. Membrane properties of induced PC12 cells. (A) A patch clamp recording was performed on induced PC12 cells. Scale bar, $20 \mu \mathrm{m}$. (B) Representative traces of membrane potentials in response to step current injections from the control cells on day 6. (C) Representative traces of the membrane action potentials in response to step current injections in PC12 cells on day 6 with the $50 \mathrm{ng} / \mathrm{ml}$ nerve growth factor treatment. All action potentials were generated in culture.

$\left(46.11 \pm 1.06 \times 10^{4}\right.$ cells $\left./ \mathrm{ml}\right)$ than the Opti-MEM group $\left(27.85 \pm 5.45 \times 10^{4}\right.$ cells $\left./ \mathrm{ml}\right)$, and the difference was maintained from day 4 to day 6 (1640 groups, $99.88 \pm 7.02 \times 10^{4}$; Opti-MEM group, $53.11 \pm 6.55 \times 10^{4}$ cells $\left./ \mathrm{ml}\right)$, which indicated that Opti-MEM medium containing $0.5 \%$ FBS can provide a better environment for inducing PC12 cells to become neurons.

The expression of synapsin-1 and GAP-43 in the Opti-MEM and 1640 groups. Differentiation of PC12 cells with $50 \mathrm{ng} / \mathrm{ml} \mathrm{NGF}$ increased the expression of synapsin-1 and GAP-43 (Fig. 5). Western blot analysis indicated that synapsin-1 levels were dramatically increased in the Opti-MEM groups than 1640 groups on days 2, 4 and 6 (Fig. 5A). The expression of GAP-43 was consistent with the synapsin-1 levels on days 2, 4 and 6, but that all the levels were dramatically increased in the Opti-MEM groups than 1640 groups (Fig. 5B). Quantification of the western blot data from the two groups is presented in Fig. 5C and D.

Action potential of the induced PC12 cells using Opti-MEM as an induction medium. Differentiation of PC12 cells with $50 \mathrm{ng} / \mathrm{ml}$ NGF had active membrane properties (Fig. 6). Whole-cell recordings were performed on day 6 following treatment with or without $50 \mathrm{ng} / \mathrm{ml}$ NGF (Fig. 6A). When the induced PC12 cells were step-depolarized, compared with the control cells without induction (Fig. 6B), the action potentials could be recorded in the induction of PC12 cells on day 6 with the $50 \mathrm{ng} / \mathrm{ml}$ NGF treatment (Fig. 6C).

\section{Discussion}

The PC12 cell line was first separated from a tumor in the adrenal medulla of a rat (12). It can reversibly react to the addition of NGF by differentiating and growing neurites (13). PC12 cells have been widely used as a neuronal in vitro model system (14), including studies on the effects of neurotoxicants on differentiation $(15,16)$. Previous studies have used different training and induction methods to transform PC12 cells into neurons, but there are some limitations that exist. First, although cells do not generate axons or dendrites or form real synapses with each other. In addition, they have the potential for gene mutation resulting in a phenotype change (17). Induced PC12 cells have a low differentiation rate, short neurite length and low adhesion rate (10-12).

In the present study, the authors used Opti-MEM medium containing $0.5 \%$ FBS and/or $1 \%$ HS compared with RPMI-1640 medium containing $0.5 \% \mathrm{FBS}$ and/or $1 \% \mathrm{HS}$. With the novel method of PC12 neural differentiation, the authors observed a significant increase in both cell differentiation number and neurite 
length on day 6 . The low variability morphological measurements were highly consistent between cultures. In addition, the study also demonstrated that adhesion of PC12 cells was significantly improved and proliferation was significantly decreased by Opti-MEM group with $50 \mathrm{ng} / \mathrm{ml}$ NGF. The Opti-MEM group with $50 \mathrm{ng} / \mathrm{ml}$ NGF showed a higher adhesive and slower proliferation effect than RPMI-1640 group. The results also demonstrated the interaction between the supplemented medium and serum in inducing PC12 to become neurons.

Axonal growth and formation of synaptic vesicles is modulated by the expression of neuronal proteins and synaptic proteins (18-23). GAP-43 and synapsin-1 are related to PC12 cell differentiation and neurite outgrowth. As an endogenous substrate for PKC, phosphorylated GAP-43 is stimulated by NGF in PC12 cells (24-26), and upregulation of GAP-43 mRNA and protein is related to the differentiation of PC12 cells (27-29). Both proteins have been identified at increased levels during the formation of mature synapses in cell development $(30,31)$. A previous report verified that GAP-43 and synapsin-1 are sensitive to chemical disruption of differentiation and neurite outgrowth (32). GAP-43 was absent on day 0 and plateaued at high levels by day 6 , and was correlated with axonal outgrowth and neurite outgrowth $(33,34)$. However, synapsin-1 increased during the differentiation of PC12 cells, and increased most prominently on day 4 following differentiation (35). Therefore, the expression of GAP-43 and synapsin-1 were evaluated as markers of axons and presynaptic vesicles (36). The current data of GAP-43 and synapsin-1 suggest that this improved method induces differentiated PC12 cells to mimic sympathetic neurons.

To identify whether induced PC12 cells had active membrane properties, whole-cell recordings were performed. When the induced PC12 cells were step-depolarized, action potentials were only detected in many $\mathrm{NGF}^{+}$cells. The cells appeared remarkably similar to neuroblastoma cells, but their results were somewhat smaller than those reported for rat sympathetic neurons. Previous studies have reported that the resting potentials of $\mathrm{NGF}^{+}$cells were -50 to -65 (37) the authors demonstrated that $\mathrm{PC} 12$ cells cultured in Opti-MEM medium containing $0.5 \%$ FBS are suitable for electrophysiological studies. Because Opti-MEM medium has more hypoxanthine and thymine than RPMI-1640, it was speculated that these nutrients affected the PC12 cell neuron differentiation potential.

In conclusion, compared with the conventional RPMI-1640 induction method, the new approach with Opti-MEM could significantly increase the induced cell neurite length, differentiation rate, adhesion rate and expression of GAP-43 and synapsin-1. The resulting morphology was more like neurons. Therefore, the present study provided an improved induction method for neural differentiation of PC12 cells using Opti-MEM medium containing $0.5 \%$ FBS, an approach that can be widely used in neurobiology and neuropharmacology research models. Admittedly, there are some limitations to this study. As previous studies have demonstrated that pathways, such as the mitogen-activated protein kinase/extracellular regulated kinase (MAPK/ERK) and the phosphatidylinositol-3 kinase (PI3K)/AKT pathways are closely related to the proliferation, differentiation and apoptosis of PC12 cells (38-41), the examination of such pathways would be valuable and this was not carried out in this study. Thus, further studies on these pathways are required to explore the full potential of using Opti-MEM medium containing 0.5\% FBS induction of PC12 cell differentiation.

\section{Acknowledgements}

The present study was funded by the Ocean and Fisheries Foundation of Guangdong Province (grant no. B201601-04), the Natural Science Foundation of China (grant nos. 81202519 and 81403202), the Science and Technology Program of Guangzhou (grant nos. 201607010216, 201510010074 and 201607010063), and was supported by Natural Science Foundation of Guangdong Province(grant nos. 2014A030313362 and 2014A030313416) and the Science and Technology Planning Project of Guangdong Province (grant nos. 2014A010105029, 2014A020211022 and 2016A020214012) and the Youth Elite Project of GUCM (grant no. QNYC20140103).

\section{References}

1. Uceda G, Artalejo AR, López MG, Abad F, Neher E and García AG: $\mathrm{Ca}(2+)$-activated $\mathrm{K}^{+}$channels modulate muscarinic secretion in cat chromaffin cells. J Physiol 454: 213-230, 1992.

2. Zhou Z and Neher E: Calcium permeability of nicotinic acetylcholine receptor channels in bovine adrenal chromaffin cells. Pflugers Arch 425: 511-517, 1993.

3. Nooney JM, Peters JA and Lambert JJ: A patch clamp study of the nicotinic acetylcholine receptor of bovine adrenomedullary chromaffin cells in culture. J Physiol 455: 503-527, 1992.

4. Horrigan FT and Bookman RJ: Releasable pools and the kinetics of exocytosis in adrenal chromaffin cells. Neuron 13: 1119-1129, 1994.

5. Shao J, Cao J, Wang J, Ren X, Su S, Li M, Li Z, Zhao Q and Zang W: MicroRNA-30b regulates expression of the sodium channel Nav1.7 in nerve injury-induced neuropathic pain in the rat. Mol Pain 12: 1744806916671523, 2016. doi: $10.1177 / 1744806916671523$.

6. Zheng W, Chong CM, Wang H, Zhou X, Zhang L, Wang R, Meng Q, Lazarovici P and Fang J: Artemisinin conferred ERK mediated neuroprotection to PC12 cells and cortical neurons exposed to sodium nitroprusside-induced oxidative insult. Free Radic Biol Med 97: 158-167, 2016.

7. Liu L, Sun T, Xin F, Cui W, Guo J and Hu J: Nerve growth factor protects against alcohol-induced neurotoxicity in PC12 cells via PI3K/Akt/mTOR pathway. Alcohol Alcohol 52: 12-18, 2017.

8. O'Callaghan JP: Neurotypic and gliotypic proteins as biochemical markers of neurotoxicity. Neurotoxicol Teratol 10: 445-452, 1988

9. Greene LA and Tischler AS: Establishment of a noradrenergic clonal line of rat adrenal pheochromocytoma cells which respond to nerve growth factor. Proc Natl Acad Sci USA 73: 2424-2428, 1976.

10. Medina Benavente JJ, Mogami H, Sakurai T and Sawada K: Evaluation of silicon nitride as a substrate for culture of PC12 cells: an interfacial model for functional studies in neurons. PLoS One 9: e90189, 2014.

11. Jeon CY, Jin JK, Koh YH, Chun W, Choi IG, Kown HJ, Kim YS and Park JB: Neurites from PC12 cells are connected to each other by synapse-like structures. Synapse 64: 765-772, 2010.

12. Chen ZA, Wang JL, Liu RT, Ren JP, Wen LQ, Chen XJ and Bian GX: Liquiritin potentiate neurite outgrowth induced by nerve growth factor in PC12 cells. Cytotechnology 60: 125-132, 2009.

13. Daniele S, Lecca D, Trincavelli ML, Ciampi O, Abbracchio MP and Martini C: Regulation of PC12 cell survival and differentiation by the new P2Y-like receptor GPR17. Cell Signal 22: 697-706, 2010.

14. Das KP, Freudenrich TM and Mundy WR: Assessment of PC12 cell differentiation and neurite growth: a comparison of morphological and neurochemical measures. Neurotoxicol Teratol 26: 397-406, 2004.

15. Thiel G: Synapsin I, synapsin II, and synaptophysin: marker proteins of synaptic vesicles. Brain Pathol 3: 87-95, 1993. 
16. Webb SJ, Monk CS and Nelson CA: Mechanisms of postnatal neurobiological development: implications for human development. Dev Neuropsychol 19: 147-171, 2001.

17. Chen J, Venkat P, Zacharek A and Chopp M: Neurorestorative therapy for stroke. Front Hum Neurosci 8: 382, 2014.

18. Benowitz LI and Routtenberg A: GAP-43: an intrinsic determinant of neuronal development and plasticity. Trends Neurosci 20: 84-91, 1997.

19. Goslin K, Schreyer DJ, Skene JH and Banker G: Changes in the distribution of GAP-43 during the development of neuronal polarity. J Neurosci 10: 588-602, 1990.

20. McGuire CB, Snipes GJ and Norden JJ: Light-microscopic immunolocalization of the growth- and plasticity-associated protein GAP-43 in the developing rat brain. Brain Res 469: 277-291, 1988.

21. Meiri KF, Willard M and Johnson MI: Distribution and phosphorylation of the growth-associated protein GAP-43 in regenerating sympathetic neurons in culture. J Neurosci 8: 2571-2581, 1988.

22. Costello B, Meymandi A and Freeman JA: Factors influencing GAP-43 gene expression in PC12 pheochromocytoma cells. J Neurosci 10: 1398-1406, 1990

23. Dani JW, Armstrong DM and Benowitz LI: Mapping the development of the rat brain by GAP-43 immunocytochemistry. Neuroscience 40: 277-287, 1991.

24. Ramakers GM, De Graan PN, Urban IJ, Kraay D, Tang T, Pasinelli P, Oestreicher AB and Gispen WH: Temporal differences in the phosphorylation state of pre- and postsynaptic protein kinase $\mathrm{C}$ substrates B-50/GAP-43 and neurogranin during long-term potentiation. J Biol Chem 270: 13892-13898, 1995.

25. Ramakers GM, Gerendasy DD and de Graan PN: Substrate phosphorylation in the protein kinase Cgamma knockout mouse J Biol Chem 274: 1873-1874, 1999.

26. Van Hooff CO, De Graan PN, Boonstra J, Oestreicher AB, Schmidt-Michels MH and Gispen WH: Nerve growth factor enhances the level of the protein kinase $\mathrm{C}$ substrate $\mathrm{B}-50$ in pheochromocytoma PC12 cells. Biochem Biophys Res Commun 139: 644-651, 1986

27. de la Torre JC, Mallory M, Brot M, Gold L, Koob G, Oldstone MB and Masliah E: Viral persistence in neurons alters synaptic plasticity and cognitive functions without destruction of brain cells Virology 220: 508-515, 1996.

28. Jap Tjoen San ER, Schmidt-Michels MH, Spruijt BM, Oestreicher AB, Schotman P and Gispen WH: Quantitation of the growth-associated protein B-50/GAP-43 and neurite outgrowth in PC12 cells. J Neurosci Res 29: 149-154, 1991.

29. Jap Tjoen San ER, Schmidt-Michels M, Oestreicher AB Schotman P and Gispen WH: Dexamethasone-induced effects on B-50/GAP-43 expression and neurite outgrowth in PC12 cells. J Mol Neurosci 3: 189-195, 1992.
30. Ehrhart-Bornstein M, Treiman M, Hansen GH, Schousboe A, Thorn NA and Frandsen A: Parallel expression of synaptophysin and evoked neurotransmitter release during development of cultured neurons. Int J Dev Neurosci 9: 463-471, 1991

31. Fletcher TL, Cameron P, De Camilli P and Banker G: The distribution of synapsin I and synaptophysin in hippocampal neurons developing in culture. J Neurosci 11: 1617-1626, 1991.

32. Eik LF, Naidu M, David P, Wong KH, Tan YS and Sabaratnam V: Lignosus rhinocerus (Cooke) ryvarden: a medicinal mushroom that stimulates neurite outgrowth in PC-12 cells. Evid Based Evid Based Complement Alternat Med 2012: 320308, 2012.

33. Greene LA and Tischler AS: Establishment of a noradrenergic clonal line of rat adrenal pheochromocytoma cells which respond to nerve growth factor. Proc Natl Acad Sci U S A 73: 2424-2428, 1976.

34. Greene LA and Tischler AS: PC12 pheochromocytoma cultures in neurobiological research. Adv Cell Neurobiol 3: 373-414, 1982.

35. Peterman MC, Bloom DM, Lee C, Bent SF, Marmor MF, Blumenkranz MS and Fishman HA: Localized neurotransmitter release for use in a prototype retinal interface. Invest Ophthalmol Vis Sci 44: 3144-3149, 2003.

36. Berger-Sweeney $\mathbf{J}$ and Hohmann CF: Behavioral consequences of abnormal cortical development: insights into developmental disabilities. Behav Brain Res 86: 121-142, 1997.

37. O'Lague PH and Huttner SL: Physiological and morphological studies of rat pheochromocytoma cells (PC12) chemically fused and grown in culture. Proc Natl Acad Sci USA 77: 1701-1705, 1980.

38. Marques-Fernandez F, Planells-Ferrer L, Gozzelino R, Galenkamp KM, Reix S, Llecha-Cano N, Lopez-Soriano J, Yuste VJ, Moubarak RS and Comella JX: TNFo induces survival through the FLIP-L-dependent activation of the MAPK/ERK pathway. Cell Death Dis 4: e493, 2013.

39. Wu PK, Hong SK, Yoon SH and Park JI: Active ERK2 is sufficient to mediate growth arrest and differentiation signaling. FEBS J 282: 1017-1030, 2015.

40. Mufti RE, Sarker K, Jin Y, Fu S, Rosales JL and Lee KY: Thrombin enhances NGF-mediated neurite extension via increased and sustained activation of p44/42 MAPK and p38 MAPK. PLoS One 9: e103530, 2014.

41. Wu SD, Xia F, Lin XM, Duan KL, Wang F, Lu QL, Cao H, Qian YH and Shi M: Ginsenoside-Rd promotes neurite outgrowth of PC12 cells through MAPK/ERK- and PI3K/AKT-dependent pathways. Int J Mol Sci 17: 17, 2016.

This work is licensed under a Creative Commons Attribution-NonCommercial-NoDerivatives 4.0 International (CC BY-NC-ND 4.0) License. 